\title{
Hormone signaling via androgen receptor affects breast cancer and prostate cancer in a male patient: A case report
}

\author{
Haruko Takuwa* (D), Wakako Tsuji, Masayuki Shintaku and Fumiaki Yotsumoto
}

\begin{abstract}
Background: Male breast cancer (MBC) is rare, accounting for only around 1\% of all breast cancers. Most MBCs are hormone-driven. Not only the estrogen receptor (ER), but also other steroid hormone receptors, including the androgen receptor (AR) and progesterone receptor (PgR) are expressed in MBC. AR activation in breast cancer cells facilitates downstream gene expression that drives tumorigenesis in a similar manner to ER. AR-mediated signalling works paradoxically in breast cancer and prostate cancer, and cancer cells expressing the AR are endocrinesensitive.
\end{abstract}

Case presentation: We describe a case of double cancer of MBC and prostate cancer. A 69-year-old man was referred to our hospital with a lump in his left breast in the 1990s. The patient had CT3N3M0, stage IIIC breast cancer, and underwent a mastectomy and axillary lymph node dissection. Though adjuvant chemotherapy was administered, he experienced pleural metastasis 2 months after the surgery. Two years after the recurrence during endocrine therapy with oral 5 -fluorouracil, he complained of frequent urination. Radiological and histological examinations revealed that the patient had CT3NOMO, stage III primary prostate cancer with a prostate-specific antigen (PSA) level of $40.5 \mathrm{ng} / \mathrm{mL}$. Germline mutations in the BRCA1 and BRCA2 genes were not tested. He received multidisciplinary, continuous therapy for both breast and prostate cancer; however, 5 and 3 years after each diagnosis, respectively, he experienced a deep vein thrombosis in his right leg related to the endocrine therapy. Liver metastasis progressed after he stopped breast cancer therapy. However, long-term disease control had been achieved with anti-estrogen therapy for breast cancer and estrogen replacement therapy for prostate cancer.

Conclusions: Several studies have shown that estrogen exposure after estrogen depletion likely causes apoptosis of ER-positive breast cancer cells. Our findings indicate that this also applies to the environment in male body. AR dominant signaling prevents breast cancer recurrence and metastasis, especially in MBC patients.

Keywords: Androgen receptor, BRCA mutation, estrogen receptor, male breast cancer, prostate cancer

\section{Background}

Male breast cancer (MBC) accounts for only around 1\% of all breast cancers [1-4]. MBC has high rates of hormone receptor expression; approximately $90-95 \%$ of all MBCs express the estrogen receptor (ER), $80-81 \%$ express the progesterone receptor (PgR), and $34-87 \%$ the androgen receptor (AR) [5-10]. Human epidermal growth factor receptor 2 (HER2)-positive $\mathrm{MBC}$ is rare [11].

* Correspondence: st24057@yahoo.co.jp

Department of Breast Surgery, Shiga General Hospital, 5-4-30, Moriyama,

Moriyama-City, Shiga 524-8524, Japan
Factors associated with an increased MBC risk are related to several genetic disorders, such as Kleinfelter's syndrome, BRCA 1/2, PTEN, p53, and CHEK2 mutations [12-17], and hormonal alterations, in particular, estrogen and androgen imbalance [15]. AR-positive patients (including female breast cancer and triple-negative breast cancer patients) respond to endocrine therapy, and have better prognoses [5, 18]. On the other hand, androgens are important for the development and maintenance of prostate cancer cells [19]. The biological function of androgens is exerted through the activation of the transcriptional activity of the AR [20-22].

(c) The Author(s). 2018 Open Access This article is distributed under the terms of the Creative Commons Attribution 4.0 International License (http://creativecommons.org/licenses/by/4.0/), which permits unrestricted use, distribution, and 
Herein, we present the case of a patient with advanced $\mathrm{MBC}$ who experienced advanced prostate cancer during systemic therapy for metastatic MBC.

\section{Case report}

A 69-year-old man presented to the outpatient clinic of the Department of Breast Surgery at the Shiga General Hospital (Moriyama, Shiga, Japan) with a lump in his left breast in the 1990s. Physical examination revealed a mass measuring $>6 \mathrm{~cm}$ without skin invasion in the upper-lateral region as well as axillary lymph node swelling. The patient had a history of diabetes, hyper tension, cerebral infarction, and brain schwannoma controlled by oral glimepiride $0.5 \mathrm{mg}$, nifedipine $40 \mathrm{mg}$, and aspirin $100 \mathrm{mg}$. He had no remarkable family history.

Ultrasonography showed a breast mass and right-sided axillary lymph node swelling. A core needle biopsy was performed, and the tumor was diagnosed as a high histological grade invasive ductal carcinoma. It was ER-positive, PgR-negative, HER2-negative and AR-positive (detected by anti-AR rabbit monoclonal antibody SP107; Roche tissue diagnostics, Ltd.); the Ki-67 labeling index was 10\% (Fig. 1).
The tumor was radiologically classified as cT3N3M0, stage IIIC disease (Union for International Cancer Control-TNM classification, 8th edition) [23].

Preoperative chemotherapy was not performed at the time; thus, a mastectomy and axillary dissection were performed. The final histological diagnosis was pt3n3a (36/39) M0, stage IIIC disease. Postoperative chemotherapy with epirubicin 40 $\mathrm{mg} /$ body with 5 -fluorouracil (5-FU) $500 \mathrm{mg} /$ body every 2 weeks plus oral cyclophosphamide $100 \mathrm{mg}$ daily (CEF) was administered. After 2 cycles of the chemotherapy, computed tomography $(\mathrm{CT})$ revealed pleural metastasis in his right lung. Anti-estrogen therapy with high-dose toremifene (TOR) $120 \mathrm{mg}$ b.i.d and oral 5-FU, doxifluridine (5'DFUR) $1200 \mathrm{mg}$ was administered as first-line therapy for metastatic breast cancer.

Two years after the recurrence, the patient complained of frequent urination. Radiological and histological examinations revealed that he had CT3NOM0, stage III primary prostate cancer (Fig. 2) with a prostate-specific antigen (PSA) level of $40.5 \mathrm{ng} / \mathrm{mL}$. He underwent radiation therapy at a dose of $66.0 \mathrm{~Gy} / 33$ fractions as local control to treat the prostate cancer. After radiotherapy,
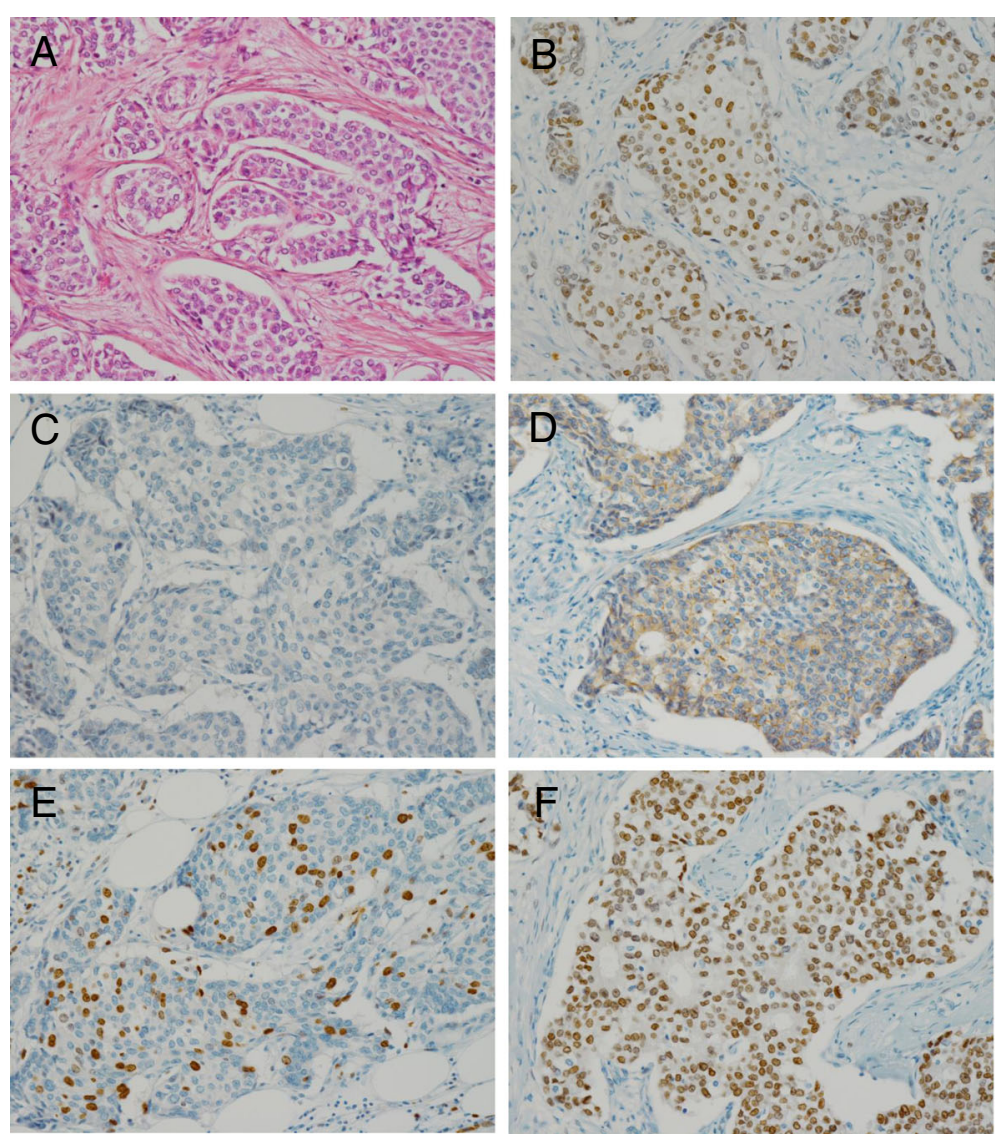

Fig. 1 a Representive photomicrographs of the breast cancer (hematoxylin-eosin staining: magnification, $\times 200$ ). Pathological examination defined the mass as invasive ductal carcinoma, histological grade 3; (b) Estrogen receptor-positive: 90\%; (c) Progesterone receptor-negative: 0\%; (d) Human epidermal growth factor receptor 2-negative: score 1+; (e) Ki-67 labeling index, 10\%; (f) Androgen receptor-positive: 95\% 

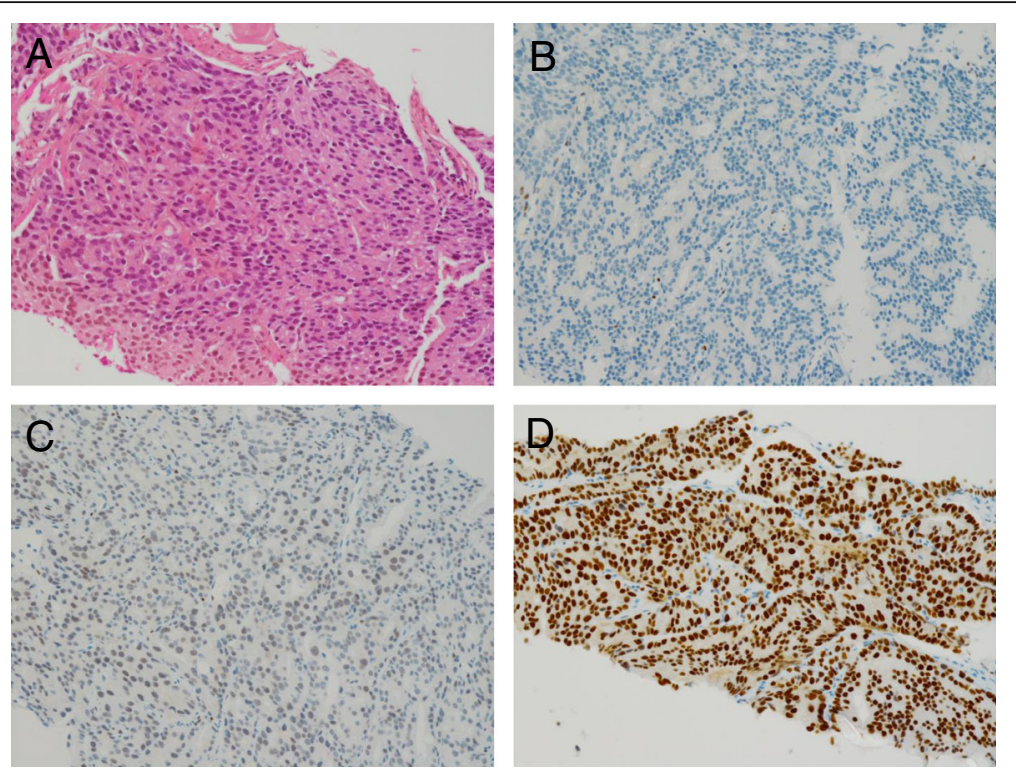

Fig. 2 a Representive photomicrographs of the prostate cancer (hematoxylin-eosin staining: magnification, $\times 200$ ). Glandular fusion is the hallmark feature of a Gleason score of 8. The image shows fused glands forming anastomosing irregular cords separated by small amounts of stroma. b Estrogen receptor-positive: 3\%; (c) Progesterone receptor-negative: 0\%; (d) Androgen receptor-positive: 95\%

the prostate cancer therapy was temporarily suspended, and the watchful waiting approach was taken. Breast cancer therapy with high-dose TOR was continued since breast cancer control was good. Six months later, the PSA level increased from $3.7 \mathrm{ng} / \mathrm{mL}$ to $18.0 \mathrm{ng} / \mathrm{mL}$. Oral estramustine phosphate sodium hydrate (Estracyt $\left.{ }^{\circ}\right) 626.8 \mathrm{mg}$ was administered daily because this drug remains specifically in prostate cancer tissue and is not contraindicated in patients with breast cancer. The PSA level immediately decreased to within the normal range $(3.7 \mathrm{ng} / \mathrm{mL})$, and Estracyt ${ }^{\circ}$ as well as TOR were continued for 3 years until the patient experienced a deep vein thrombosis in his right leg related to the endocrine therapy, while the antiplatelet therapy was ongoing.

TOR was stopped but Estracyt ${ }^{\circ}$ was continued for symptomatic disease control. A CT scan revealed liver metastasis from the breast cancer after the patient stopped the breast cancer therapy. Estracyt ${ }^{\circ}$ was changed to the non-steroidal anti-androgen agent, Casodex $x^{\oplus}$ as the second-line endocrine therapy for the prostate cancer and a luteinizing hormonereleasing hormone (LHRH) agonist as third-line treatment; however, the patient died due to breast cancer progression 5 years after the diagnosis of prostate cancer (Fig. 3).

We retrospectively reviewed the medical records of 1431 patients with breast cancer who underwent breast cancer therapy at the Shiga General Hospital between 1998 and 2017. The retrospective review of the medical records was approved by the appropriate ethics review board, and the study complied with the tenets of the Declaration of Helsinki. Of all patients, $8(0.6 \%)$ were men; they were diagnosed with primary breast cancer histologically. Table 1 shows the clinicopathological characteristics of the patients with MBC.

\section{Discussion}

We report the case of a patient with both, MBC and prostate cancer, in whom using Estracyt ${ }^{\circ}$ as estrogen replacement therapy after anti-estrogen therapy with high-dose TOR resulted in better control of breast cancer than prostate cancer for a few years.

Men with BRCA1/2 mutations are at increased risk for breast, prostate, pancreatic and other cancers $[2,3,14,16]$. Especially in individuals with the BRCA2 mutation, prostate cancer is the most commonly diagnosed cancer, followed by MBC [16]. Though a BRCA2 mutation was strongly suspected in this case based on the history of the patient (diagnosis with high-grade histology and advanced-stage breast and prostate cancer), genetic testing was not available 20 years ago. Because the patient was already deceased, a germ line mutation was not tested. Previous studies showed that $\mathrm{MBC}$ with a $B R C A$ mutation is sensitive to systemic therapy, and patients have a favorable overall survival $[14,16,24]$.

Though the dose of CEF that the patient received was lower than the doses prescribed recently, the primary breast cancer of this patient was potentially chemotherapy-resistant $[25,26]$. The metastatic site of the right pleura was small and asymptomatic, and the cancer cells were endocrine therapy-naïve and were thus expected to be endocrine-sensitive and anthracycline-resistant. High-dose TOR with oral 5-FU were administered as first-line therapy for the metastatic breast cancer. At the time, the options of endocrine therapy were tamoxifen or TOR as selective 


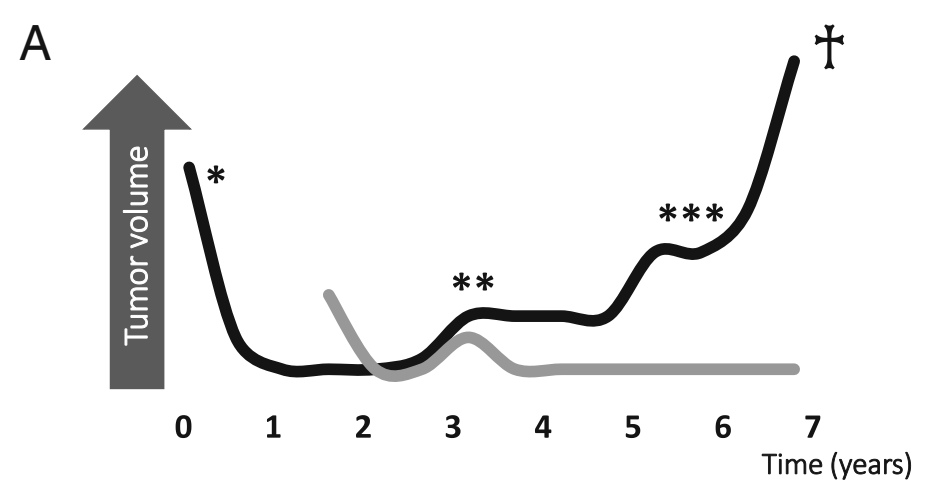

\section{Breast cancer}

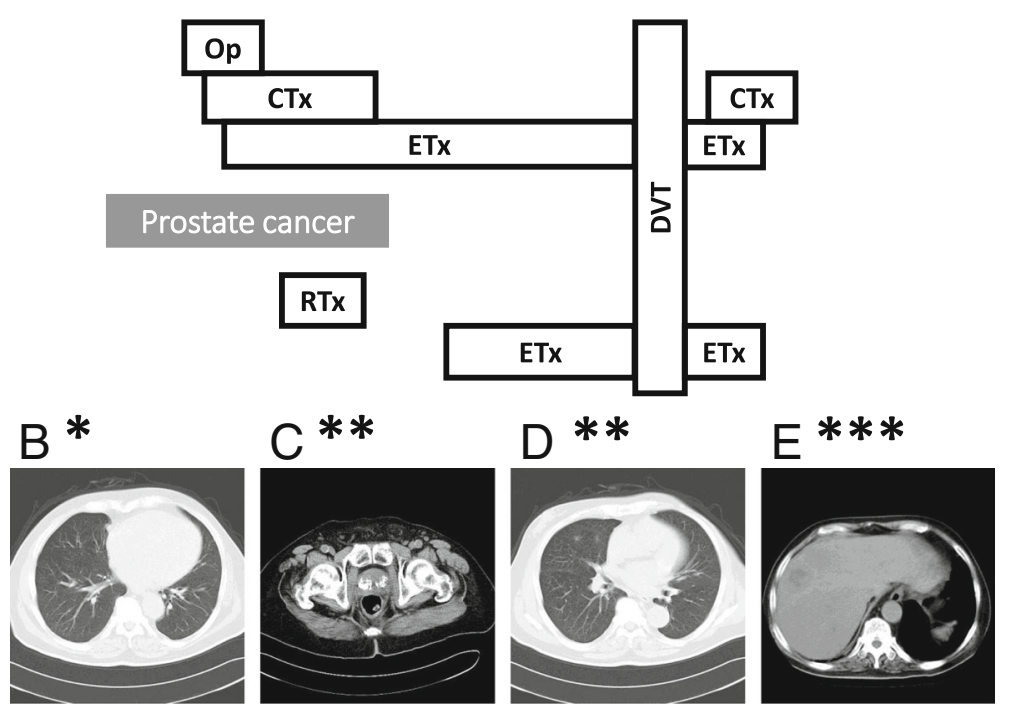

Fig. 3 Clinical course in the patient. a History of breast and prostate cancer treatment; (b) The images show $\left(^{*}\right)$ when the patient was diagnosed with pleural metastasis; $(\mathbf{c})\left({ }^{* *}\right)$ for prostate cancer recurrence with prostate-specific antigen elevation; and $(\mathbf{d})\left(^{* *}\right)$ for new regions of lung metastases. $\left.\mathbf{e}^{(* *}\right)$ The patient experienced liver metastasis when he temporarily stopped systemic therapy for breast cancer. Abbreviations: Op $=$ operation; $C T x=$ chemotherapy; $E T x=$ endocrine therapy; $R T x=$ radiotherapy; DVT = deep venous thrombosis

estrogen receptor modulators (SERM). High-dose TOR was recommended as it was expected to be more effective for cancer that is primary therapy-resistant [27-29].

Generally, SERMs have no predictive marker that indicates their biological efficiency, unlike LHRH agonists and AI do with the estrogen level. Furthermore, the active metabolite of tamoxifen, endoxifen is generated through hepatic enzyme chytochrome P450 (CYP) CYP2D6 and CYP3A. And genetic variants of CYP2D6 may affect response to tamoxifen [30]. On the other hand, a higher preoperative serum estradiol (E2) level was reported to be a negative prognostic factor in female breast cancer patients without E2 depletion [31]. Estrogen exposure after estrogen depletion was observed to cause apoptosis of ER-positive breast cancer cells in several studies in both pre- and postmenopausal women [32-34]. Our patient was exposed high serum levels of estrogen in the form Estracyt ${ }^{\circ}$ as prostate cancer therapy after 3 years of SERM.
The serum level of E2 which, among the estrogens, has the strongest physiological activity as a stimulator in ER-positive breast cancer, ranges between $20 \mathrm{pg} / \mathrm{mL}$ and $60 \mathrm{pg} / \mathrm{mL}$ in healthy men. Surprisingly, the E2 level increases up to $2-6 \mathrm{ng} / \mathrm{mL}$ during Estracyt ${ }^{\circ}$ treatment [35]. In our patient, the metastases were relatively controllable during treatment with high-dose TOR and Estracyt ${ }^{\circ}$. This finding in line with the suppression of cancer cell proliferation regardless of E2 level dynamics in premenopausal patients with breast cancer undergoing SERM therapy. After a 3-month break of systemic therapy for metastatic breast cancer, high-dose TOR was re-administered; however, it was not effective for the new liver metastasis. Importantly, first line-therapy for metastatic breast cancer had been effective for 5 years.

Another mechanism was dependent on AR-mediated downregulation of tumorigenic signal transduction. AR-positive patients, including female breast cancer and 
Table 1 Clinicopathological characteristics of the patients with male breast cancer

\begin{tabular}{|c|c|c|c|c|c|c|c|c|c|c|c|}
\hline age & $\begin{array}{l}\text { TNM } \\
\text { classification }\end{array}$ & histology & $\begin{array}{l}\text { ER } \\
(\%)\end{array}$ & $\begin{array}{l}\mathrm{PgR} \\
(\%)\end{array}$ & $\begin{array}{l}\text { HER2 } \\
\text { (FISH) }\end{array}$ & $\begin{array}{l}\text { AR } \\
(\%)\end{array}$ & $\begin{array}{l}\text { Ki-67 } \\
(\%)\end{array}$ & $\begin{array}{l}\text { Histological } \\
\text { grade }\end{array}$ & Radiation & Adjuvant therapy & Follow up (months), Outcome \\
\hline 47 & T2NOMO & IDC & 99 & 80 & $1+$ & 60 & 50 & $2(2 / 3 / 1)$ & - & $\begin{array}{l}\text { pre; TC (4) } \\
\text { post; cape+TAM }\end{array}$ & 8 \\
\hline 58 & T1bNOMO & IDC & 99 & 40 & $1+$ & 20 & 20 & $2(3 / 2 / 1)$ & - & post; TAM & 27 \\
\hline 63 & T1aNOMO & IDC & 99 & 80 & $1+$ & 90 & 10 & $1(2 / 2 / 1)$ & $\begin{array}{l}60 \mathrm{~Gy} / \\
30 \mathrm{fr} \\
\text { (WBRT) }\end{array}$ & - & 48 \\
\hline 63 & T1CNOMO & IDC & 90 & 80 & $\begin{array}{l}2+ \\
(1.54)\end{array}$ & 95 & 70 & $3(3 / 2 / 3)$ & - & post; TAM & 90 \\
\hline 69 & T3N3aM0 & IDC & 90 & 0 & $1+$ & 95 & 10 & $3(3 / 3 / 2)$ & - & $\begin{array}{l}\text { post; CEF (2) } \\
\text { MBC; TOR + 5'DFUR } \\
\text { wPTX }\end{array}$ & $\begin{array}{l}76 \\
\text { deceased }\end{array}$ \\
\hline 72 & T2N3aM0 & IDC & 99 & 90 & $\begin{array}{l}2+ \\
(2.26)\end{array}$ & 90 & 30 & $2(3 / 2 / 1)$ & $\begin{array}{l}50 \mathrm{~Gy} / \\
25 \mathrm{fr} \\
\text { (PMRT) }\end{array}$ & $\begin{array}{l}\text { pre; wPTX + } \\
\text { trastuzumab (4) } \\
\text { post; TAM + } \\
\text { trastuzumab (13) }\end{array}$ & 14 \\
\hline 74 & T2NOMO & IDC & 95 & 95 & 0 & 95 & 15 & $1(2 / 2 / 1)$ & - & post; TAM & $\begin{array}{l}56 \\
\text { Local recurrence, bone meta } \\
\text { at } 24 \text { months }\end{array}$ \\
\hline 74 & T2NOMO & mucinous & 80 & 80 & 0 & 80 & $<1$ & - & - & post; TAM & 57 \\
\hline
\end{tabular}

triple-negative breast cancer patients, respond to endocrine therapy and have better prognoses $[5,18]$. In human prostate cancer, ER- $\beta$ is silenced in cancers that are not well differentiated [36]. The AR causes the proliferation and secretion of prostate tissue whereas ER- $\beta$ suppresses its proliferation and promotes differentiation. The prostate cancer did not express ER in this patient (Fig. 2b) when he underwent prostate biopsy during anti-estrogen therapy for metastatic breast cancer. The AR works paradoxically between breast cancer cells and in prostate cancer cells. The AR and PgR have similar structures, and the AR mediates tumorigenic signal downregulation in castration-resistant prostate cancer [37, 38]. Anti-androgen therapy was not performed as the initial systemic therapy for prostate cancer in this patient; it may have prolonged the control of both breast cancer and prostate cancer. After exposure to endocrine therapy, some mutation related with endocrine-resistance in cancer cells are detected by sequencing or molecular testing. The weakness of this study was that such testing was not performed for this patient. However, estrogen exposure after estrogen depletion might be effective strategy for ER-positive metastatic breast cancer in such situation with endocrineresistance.

All patients with $\mathrm{MBC}$ patients expressed the ER and AR (Table 1). Besides the patient of the case report, one patient experienced local recurrence due to biopsy tract implantation. All patients had a relatively long prognosis although cases of locally advanced breast cancer and high histological grade disease were included. This might indicate a better endocrine sensitivity of AR-expressing breast cancer.
Endocrine therapy for both breast and prostate cancer is difficult to balance both diseases. This is because endocrine therapy for breast cancer and prostate cancer acts sometimes cooperatively, and sometimes against with conflicting mechanisms. Again, we would like to emphasize our case underwent estrogen exposure after estrogen depletion, and this strategy might be effective for ER- and AR-positive metastatic breast cancer patients.

\section{Conclusion}

The patient of this report who had double, breast and prostate cancer, showed good long-term control of both diseases. He may have had a BRCA mutation. AR-mediated signalling works paradoxically in breast cancer and prostate cancer, and cancer cells expressing the AR are endocrinesensitive. Thus, high-dose TOR and Estracyt ${ }^{\circ}$ after high dose TOR were effective in this case.

\section{Abbreviations}

5'DFUR: 5-fluorouracil, doxifluridine; 5-FU: 5-fluorouracil; AR: androgen receptor; CEF: cyclophosphamide, epirubicine and 5-fluorouracil;

$C T$ : compute tomography; E2: estradiol; ER: estrogen receptor; HER2: human epidermal growth factor receptor 2; LHRH: luteinizing hormone-releasing hormone; MBC: male breast cancer; PgR: progesterone receptor;

PSA: prostate-specific antigen; SERM: selective estrogen receptor-modulator; TOR: toremifene

\section{Acknowledgements}

None.

\section{Funding}

This research did not receive any specific grant from funding agencies in the public, commercial, or not-for-profit sectors.

\section{Availability of data and materials}

All the data supporting the findings are presented within the manuscript and supplementary data. 


\section{Authors' contributions}

HT, WT, FY participated in the treatment, data interpretation and manuscript preparation. MS performed the histopathological diagnosis and the immunohistochemistry. HT wrote and edited the manuscript. All authors read and approved the final manuscript.

\section{Ethics approval and consent to participate}

As it is a case report, ethics approval is not necessary after consulting the Ethics Committee of Shiga General Hospital.

\section{Consent for publication}

Written informed consent was obtained from the patient and his wife for publication of this case report and any accompanying images.

\section{Competing interests}

The authors declare that they have no competing interests.

\section{Publisher's Note}

Springer Nature remains neutral with regard to jurisdictional claims in published maps and institutional affiliations.

Received: 18 April 2018 Accepted: 13 December 2018 Published online: 22 December 2018

\section{References}

1. Siegel RL, Miller KD, Jemal A. Cancer statistics, 2018. CA Cancer J Clin. 2018;68:7-30.

2. Ruddy KJ, Winer EP. Male breast cancer: risk factors, biology, diagnosis, treatment, and survivorship. Ann Oncol Off J Eur Soc Med Oncol. 2013;24:1434-43.

3. Rizzolo P, Silvestri V, Tommasi S, Pinto R, Danza K, Falchetti M, et al. Male breast cancer: genetics, epigenetics, and ethical aspects. Ann Oncol Off J Eur Soc Med Oncol. 2013;24(Suppl 8):viii75-82.

4. Speirs V, Shaaban AM. The rising incidence of male breast cancer. Breast Cancer Res Treat. 2009:115:429-30.

5. Severson TM, Zwart W. A review of estrogen receptor/androgen receptor genomics in male breast cancer. Endocr Relat Cancer. 2017;24:R27-34.

6. Nilsson C, Koliadi A, Johansson I, Ahlin C, Thorstenson S, Bergkvist L, et al. High proliferation is associated with inferior outcome in male breast cancer patients. Mod Pathol. 2013;26:87-94.

7. Anderson WF, Jatoi I, Tse J, Rosenberg PS. Male breast cancer: a populationbased comparison with female breast cancer. J Clin Oncol. 2010;28:232-9.

8. White J, Kearins O, Dodwell D, Horgan K, Hanby AM, Speirs V. Male breast carcinoma: increased awareness needed. Breast Cancer Res. 2011:13:219.

9. Peters AA, Buchanan G, Ricciardelli C, Bianco-Miotto T, Centenera MM, Harris $J M$, et al. Androgen receptor inhibits estrogen receptor-alpha activity and is prognostic in breast cancer. Cancer Res. 2009;69:6131-40.

10. Chia K, O'Brien M, Brown M, Lim E. Targeting the androgen receptor in breast cancer. Curr Oncol Rep. 2015;17:4.

11. Cardoso F, Bartlett JMS, Slaets L, van Deurzen CHM, van Leeuwen-Stok E, Porter $\mathrm{P}$, et al. Characterization of male breast cancer: results of the EORTC 10085/TBCRC/BIG/NABCG international male breast Cancer program. Ann Oncol Off J Eur Soc Med Oncol. 2018;29:405-17.

12. Evans DB, Crichlow RW. Carcinoma of the male breast and Klinefelter's syndrome: is there an association? CA Cancer J Clin. 1987;37:246-51.

13. Ewertz M, Holmberg L, Tretli S, Pedersen BV, Kristensen A. Risk factors for male breast cancer--a case-control study from Scandinavia. Acta Oncol. 2001;40:467-71.

14. Liede A, Karlan BY, Narod SA. Cancer risks for male carriers of germline mutations in BRCA1 or BRCA2: a review of the literature. J Clin Oncol. 2004;22:735-42.

15. Korde LA, Zujewski JA, Kamin L, Giordano S, Domchek S, Anderson WF, et al. Multidisciplinary meeting on male breast cancer: summary and research recommendations. J Clin Oncol. 2010;28:2114-22.

16. Ibrahim M, Yadav S, Ogunleye F, Zakalik D. Male BRCA mutation carriers: clinical characteristics and cancer spectrum. BMC Cancer. 2018;18:179.

17. Meijers-Heijboer $H$, van den Ouweland A, Klijn J, Wasielewski M, de Snoo A, Oldenburg $\mathrm{R}$, et al. Low-penetrance susceptibility to breast cancer due to CHEK2 $\left.{ }^{*}\right) 1100$ delC in noncarriers of BRCA1 or BRCA2 mutations. Nat Genet. 2002;31:55-9.

18. Adamo B, Ricciardi GRR, leni A, Franchina T, Fazzari C, Sanò MV et al. The prognostic significance of combined androgen receptor, E-cadherin, Ki67 and CK5/6 expression in patients with triple negative breast cancer. Oncotarget. 2017;8:76974-86.
19. Visakorpi T, Hyytinen E, Koivisto P, Tanner M, Keinänen R, Palmberg C, et al. In vivo amplification of the androgen receptor gene and progression of human prostate cancer. Nat Genet. 1995;9:401-6.

20. Harris WP, Mostaghel EA, Nelson PS, Montgomery B. Androgen deprivation therapy: progress in understanding mechanisms of resistance and optimizing androgen depletion. Nat Clin Pract Urol. 2009;6:76-85.

21. Cai C, He HH, Chen S, Coleman I, Wang H, Fang Z, et al. Androgen receptor gene expression in prostate cancer is directly suppressed by the androgen receptor through recruitment of lysine-specific demethylase 1. Cancer Cell. 2011;20:457-71.

22. Guo W, Keener $A L$, Jing $Y$, Cai $L, A i$ J, Zhang J, et al. FOXA1 modulates EAF2 regulation of $A R$ transcriptional activity, cell proliferation, and migration in prostate cancer cells. Prostate. 2015;75:976-87.

23. Union for International Cancer Control-TNM classification, $8^{\text {th }}$ edition. 2016.

24. Giordano SH. A review of the diagnosis and management of male breast cancer. Oncologist. 2005;10:471-9.

25. Rivera $\mathrm{E}, \mathrm{Gomez} \mathrm{H}$. Chemotherapy resistance in metastatic breast cancer: the evolving role of ixabepilone. Breast Cancer Res. 2010;12(Suppl 2):S2.

26. Hamilton A, Roy JA, Beex L, Piccart M, Mauriac L, Coleman R, et al. EORTC 10941: a phase II study of liarozole in postmenopausal patients with 'chemotherapy-resistant' or 'potentially hormone sensitive' metastatic breast cancer. Breast Cancer Res Treat. 2000:60:181-8.

27. Sawaki M, Wada M, Sato Y, Mizuno Y, Kobayashi H, Yokoi K, et al. High-dose toremifene as first-line treatment of metastatic breast cancer resistant to adjuvant aromatase inhibitor: a multicenter phase II study. Oncol Lett. 2012;3:61-5.

28. Yamamoto Y, Masuda N, Ohtake T, Yamashita H, Saji S, Kimijima I, et al. Clinical usefulness of high-dose toremifene in patients relapsed on treatment with an aromatase inhibitor. Breast Cancer. 2010;17:254-60.

29. Stenbygaard LE, Herrstedt J, Thomsen JF, Svendsen KR, Engelholm SA, Dombernowsky P. Toremifene and tamoxifen in advanced breast cancer--a double-blind cross-over trial. Breast Cancer Res Treat. 1993:25:57-63.

30. Binkhorst L, Mathijssen RHJ, Jager A, van Gelder T. Individualization of tamoxifen therapy: much more than just CYP2D6 genotyping. Cancer Treat Rev. 2015;41:289-99.

31. Kim JY, Han W, Moon HG, Ahn SK, Kim J, Lee JW, et al. Prognostic effect of preoperative serum estradiol level in postmenopausal breast cancer. BMC Cancer. 2013;13:503.

32. Iwase H, Yamamoto Y, Yamamoto-Ibusuki M, Murakami Kl, Okumura Y, Tomita S, et al. Ethinylestradiol is beneficial for postmenopausal patients with heavily pre-treated metastatic breast cancer after prior aromatase inhibitor treatment: a prospective study. Br J Cancer. 2013;109:1537-42.

33. Lewis JS, Meeke K, Osipo C, Ross EA, Kidawi N, Li T, et al. Intrinsic mechanism of estradiol-induced apoptosis in breast cancer cells resistant to estrogen deprivation. J Natl Cancer Inst. 2005:97:1746-59.

34. Takuwa H, Saji S, Takada M, Takahara S, Yamauchi, A. The relationship between serum E2 levels and recurrence in premenopausal, ER-positive breast cancer patients: a retrospective study. Breast Dis 2018; Epub ahead of print. doi:https://doi.org/10.3233/BD-170307.

35. Gunnarsson PO, Forshell GP. Clinical pharmacokinetics of estramustine phosphate. Urology. 1984:23:22-7.

36. Imamov O, Lopatkin NA, Gustafsson JA. Estrogen receptor beta in prostate cancer. N Engl J Med. 2004;351:2773-4

37. Lai J, Myers SA, Lawrence MG, Odorico DM, Clements JA. Direct progesterone receptor and indirect androgen receptor interactions with the kallikrein-related peptidase 4 gene promoter in breast and prostate cancer. Mol Cancer Res. 2009;7:129-41.

38. Gui B, Hsieh CL, Kantoff PW, Kibel AS, Jia L. Androgen receptor-mediated downregulation of microRNA-221 and -222 in castration-resistant prostate cancer. PLoS One. 2017;12:e0184166. 